\title{
Nutrient Profile of Some Important Native Fishes of Nepal
}

\author{
Md. Akbal Husen ${ }^{1, *}$, Tek Bahadur Gurung ${ }^{2}$, Archana Prasad ${ }^{3}$, Sweety Nakarmi ${ }^{3}$, Neeta Pradhan ${ }^{4}$, \\ Ram Kumar Shrestha ${ }^{1}$, Agni Prasad Nepal ${ }^{1}$
}

${ }^{1}$ Fishery Research Station, Begnas, Kaski, Nepal.

${ }^{2}$ Nepal Agricultural Research Council (NARC), Singhdarbar, Plaza, Kathmandu, Nepal.

${ }^{3}$ Department of Zoology, Tribhuvan University, Kathmandu, Bagmati Province, Nepal.

${ }^{4}$ National Fisheries Research Center, Godawari, Lalitpur, Nepal.

\begin{abstract}
How to cite this paper: Md. Akbal Husen, Tek Bahadur Gurung, Archana Prasad, Sweety Nakarmi, Neeta Pradhan, Ram Kumar Shrestha, Agni Prasad Nepal. (2021) Nutrient Profile of Some Important Native Fishes of Nepal. International Journal of Food Science and Agriculture, 5(3), 455-464.

DOI: 10.26855/ijfsa.2021.09.016
\end{abstract}

Received: June 30, 2021

Accepted: July 27, 2021

Published: August 23, 2021

*Corresponding author: Md. Akbal Husen, Fishery Research Station, Begnas, Kaski, Nepal.

Email: akbalhusen@yahoo.com

\begin{abstract}
Fish as a healthy food is increasing popularity worldwide because of their higher PUFA (poly unsaturated fatty acid) concentration. Contrarily, we have limited knowledge of nutritional composition of native fishes. The data base on nutrient contents of the native fishes may have wider application to recommend dietary plan to combat nutritional deficiencies in women and children and other consumers. To fill such gap of information, this study has documented the nutrient profile of eleven important native fish species of Nepal. Sample of fresh native fish were collected from one of Central Himalayan, the Begnas Lake, identified in species level in the year 2019-2020. The fish were subjected to proximate and minerals analysis on oven dry weight basis. The results showed that nutrients and minerals contents were varied from species to species. The range of crude protein (\%), moisture (\%), ash (\%), phosphorus (mg/100g), iron (mg/100g) and calcium (mg/100g) were from 43.5 to $66.1,4.7$ to $8.4,6.2$ to $17.3,917.0$ to $4,510.8$, $1.7-12.36$ and 3,442.5-6,282.5, respectively. This present study will be useful to make the dietary plan of the people of this region/Nepal.
\end{abstract}

\section{Keywords}

Nutrients, minerals, dietary plan, nutritional deficiencies, native fish, Begnas Lake

\section{Introduction}

Recently, there is an increasing interest among the general consumers worldwide to consume fish as a food because of their high PUFA content and health concern of people. Fish is a good source of key nutrient such as highly bioavailable animal protein [1, 2, 3]. Fish plays a crucial role in global food and nutrition security (FNS) as it represents an important and nutrient dense animal source food [4,5]. Fish represents a relatively cheap and easily available mean for nutritional diversification in several Low \& middle income countries (LMICs) where diets depend heavily on a narrow range of staple foods $[5,6]$.

Information of the nutrient composition of important foods is a valuable tool to understand the links between food production, access and nutrient intakes in devising policies and programme such as development of improved production technologies [7]. Many earlier studies have documented the nutritional aspects of native fish species of their specific area in the global $[8,9,10,11,12]$. These studies have emphasized the importance about knowledge of nutritional composition of native fish species for recommendation of dietary plan of respective area to combat with nutritional deficiencies in general people specially to women and children. The nutritional composition of same species has been found to vary by region, season, age of the fish and sex etc. [13, 14]. Therefore, estimating the nutrient composition of edible fish is the most important aspect of fish nutrition [15], which might have implication to enhance the value of native fishes from conservation as well as production perspectives. 
Nepal is home of great diversity of fish species and includes 232 native fish in the country [16]. Pokhara valley is a cluster of nine lakes and Begnas is the second largest Lake in the valley. A total of 26 fish species have been recorded including 20 native and 6 non-native species from three lakes (Phewa, Begnas and Rupa) of the Pokhara valley. The amount of the total harvested fish from three lakes (Phewa, Begnas and Rupa) of Pokhara Valley in 2016/17 was 118.5 metric tons [17].

Malnutrition in women and child still exists a serious concern in Nepal [18]. In general, fish as a food is acceptable to all across Nepal [19]. Indeed, fish is an important source of animal protein, which could be a support for avoiding malnutrition being suffered by the general people of the Nepal. However, the role of the inland water fisheries for the food and nutritional security in Himalayan landlocked country has been ignored [19]. Probably, increasing fish consumption may solve this problem by providing necessary nutritional requirement. In future, the people of Nepal will dependent on fish for nutritional food due to health concern. It is necessary to know the nutritional composition of native fish species to recommend the dietary plan to the people to overcome nutritional deficiencies.

Knowledge of nutritional composition of native fish species for recommendation of dietary plan of respective area to combat with nutritional deficiencies in women and children is necessary in Nepal. However, knowledge concerning the nutritional value and quality of the commercially important native fishes of Nepal is limited. One study had earlier reported on the importance of different small indigenous fish (SIS) fish species, dedhuwa, Esomus danricus, and pothi, Puntius sophore consumption from ponds [20] and some studies had reported nutrients analysis of sun-dried/smoked fish samples collected from the local market of Nepal [21, 22, 23, 24], while selecting fish for diet in Nepal. This study was aimed to assess and document the nutrients and minerals profile of important native fish species of Begnas Lake.

\section{Materials and Methods}

\subsection{Study area}

\section{Begnas Lake}

Begnas Lake is the second biggest lake (328 ha) among the Pokhara Valley Lakes situated in Central Himalaya, at $28^{\circ} 10^{\prime} 26.2^{\prime \prime} \mathrm{N}$ and $84^{\circ} 05^{\prime} 50.4^{\prime \prime} \mathrm{E}, 650 \mathrm{~m}$ above mean sea level (Figure 1). It is fed by a perennial stream with a catchment area of $19 \mathrm{~km}^{2}$ and an average depth of $6.6 \mathrm{~m}$. This lake fluctuates between oligotrophic and mesotrophic in different seasons [25].

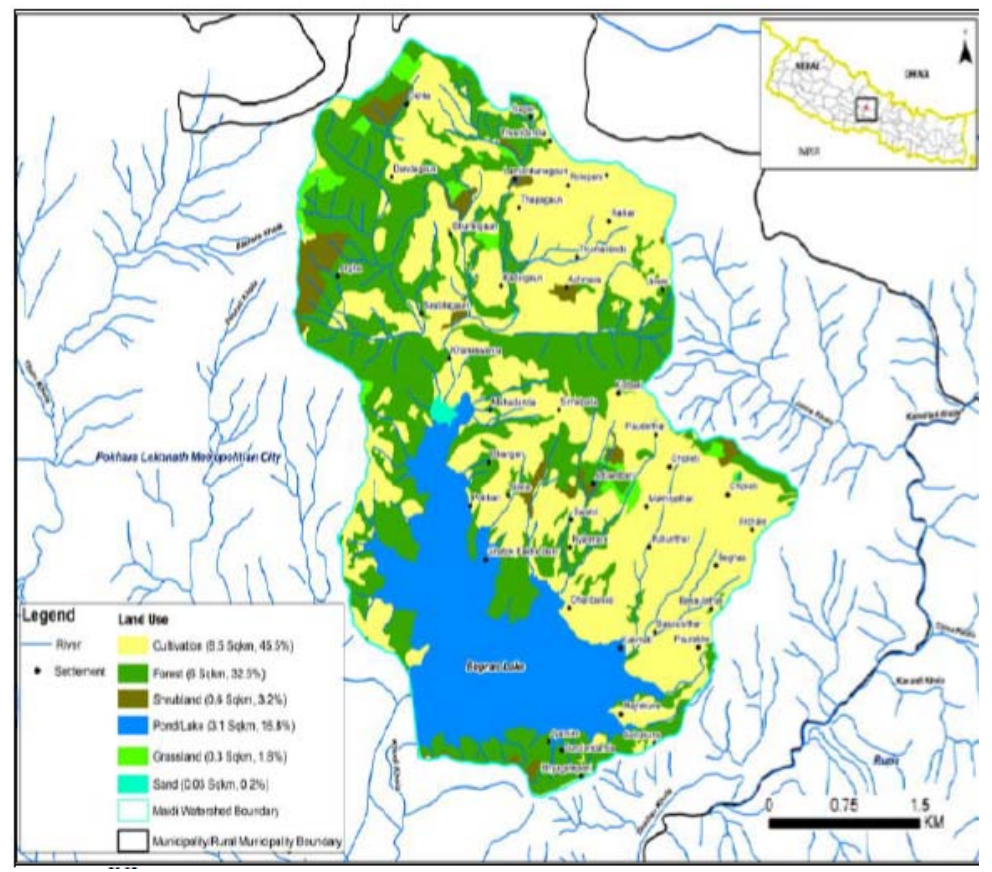

Figure 1. Location map of Begnas Lake [26].

\subsection{Collection and identification of fish}

Samples of native fish species were collected from Begnas Lake by using gillnet, cast net, hook and line. The fish samples were persevered in icebox and brought to laboratory of Fishery Research Station, Begnas Lake. The collected fish species were identified using the keys given in the book "Ichthyology of Nepal" [27]. After identification, the individual, total body weight in grams (g) was measured, which is presented in Table 1 and Figures 2A-2K. 
Table1. Local name, scientific name, order, family and mean body weight mean \pm standard deviation (mean \pm SD) of fish species collected from Begnas Lake of Pokhara valley

\begin{tabular}{|c|c|c|c|c|c|}
\hline S.N. & Local name & Scientific name & Order & Family & $\begin{array}{l}\text { Fish weight (g) } \\
\text { (mean } \pm \text { SD) }\end{array}$ \\
\hline 1 & Sahar & Tor putitora & Cypriniformes & Cyprinidae & $230 \pm 3.20$ \\
\hline 2 & Rohu & Labeo rohita & Cypriniformes & Cyprinidae & $1,525 \pm 23.05$ \\
\hline 3 & Rewa & Cirrhinus reba & Cypriniformes & Cyprinidae & $145.74 \pm 14.03$ \\
\hline 4 & Bhitte & Puntius sophore & Cypriniformes & Cyprinidae & $4.07 \pm 0.10$ \\
\hline 5 & Bhitte/Rato pothi & Puntius conchonius & Cypriniformes & Cyprinidae & $4.02 \pm 0.02$ \\
\hline 6 & Sera Bhitte & Danio devario & Cypriniformes & Cyprinidae & $3.47 \pm 0.28$ \\
\hline 7 & Fageta & Barilius barna & Cypriniformes & Cyprinidae & $5.08 \pm 1.05$ \\
\hline 8 & Chuchhe Bam & Mastacembelus armatus & Synbranchiformes & Mastacembelidae & $18.02 \pm 1.20$ \\
\hline 9 & Dunge Bam & Xenontodon cancilla & Beloniformes & Belonidae & $10.50 \pm 2.37$ \\
\hline 10 & Junge Machha & Mystus bleekeri & Siluriformes & Bagaridae & $5.98 \pm 3.38$ \\
\hline 11 & Bhoti & Channa punctatus & Perciformes & Channidae & $10.51 \pm 2.37$ \\
\hline
\end{tabular}

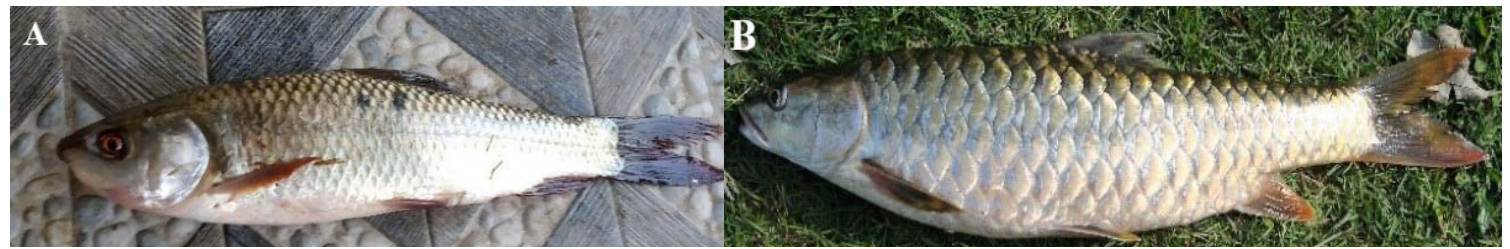

(A) Labeo rohita

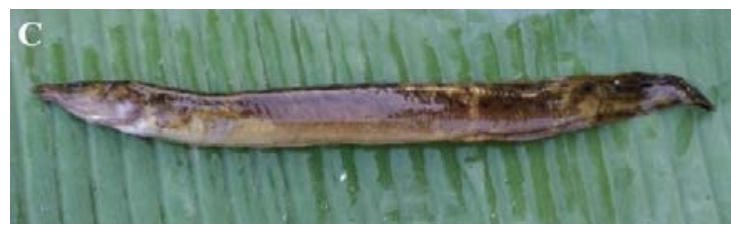

(C) Mastacembelus armatus
(B) Tor putitora

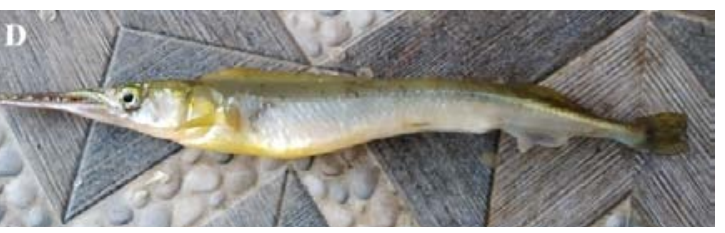

(D) Xenentodon cancila

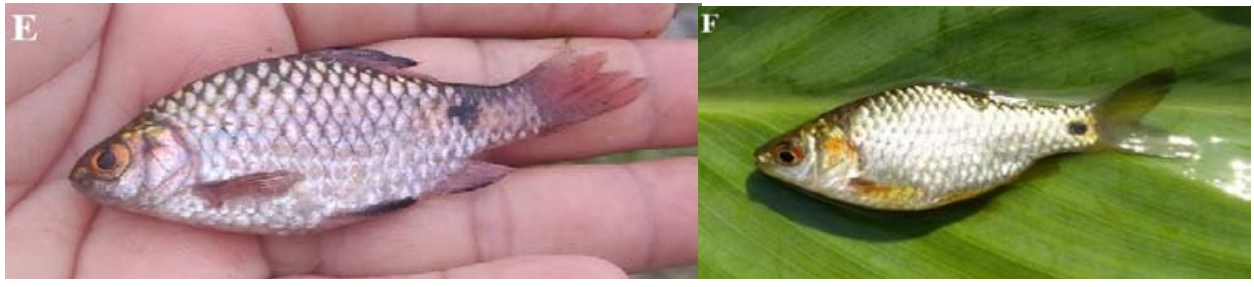

(E) Puntius conchonius

(F) Puntius sophore

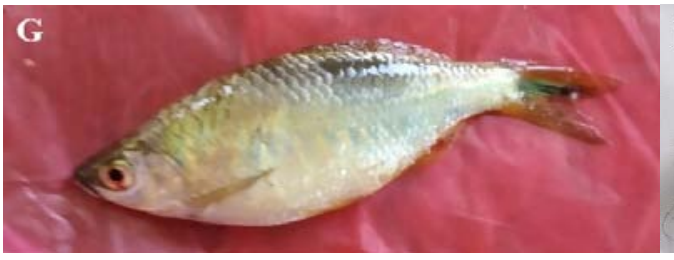

(G) Danio devario

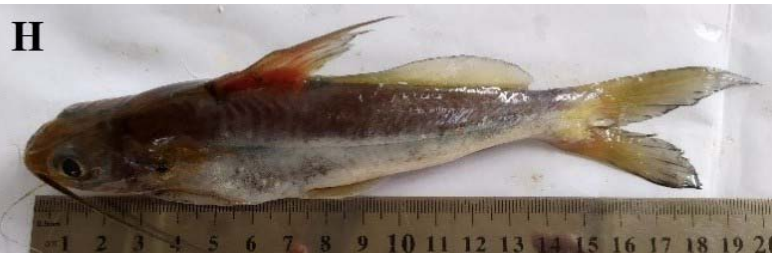

(H) Mystus bleekeri

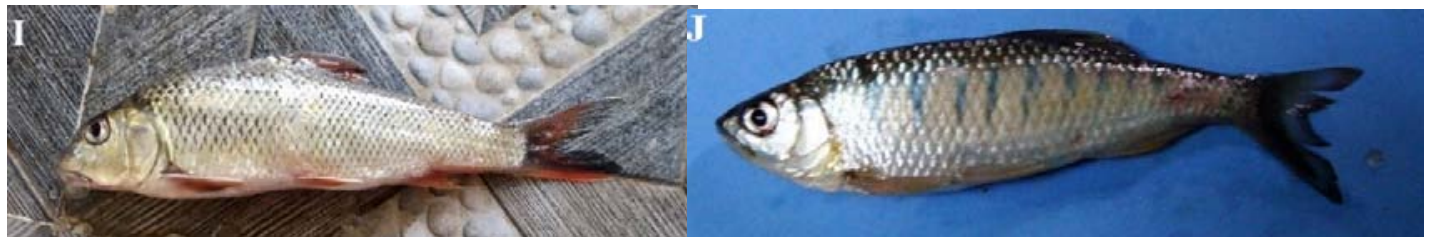

(I) Cirrhinus reba

(J) Barilius barna 


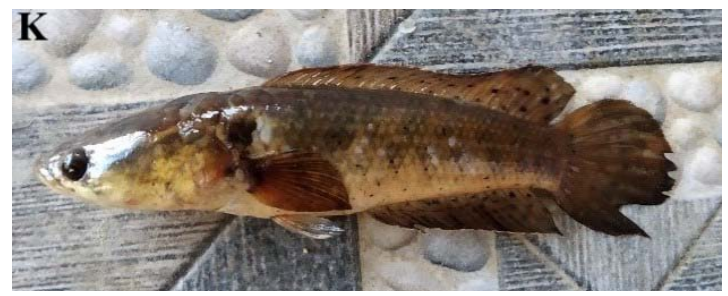

(K) Channa punctatus

Figure 2. Photos of fish species collected from Begnas Lake: Labeo rohita (A), Tor putitora (B), Mastacembelus armatus (C), Xenentodon cancila (D), Puntius conchonius (E), Puntius sophore (F), Danio devario (G), Mystus bleekeri (H), Cirrhinus reba (I), Barilius barna (J), Channa punctatus (K).

\subsection{Preparations of samples for analysis}

Samples were washed with tap water, descaled, gutted, eviscerated and washed again with tap water. The weight of gutted fish was measured and kept in the oven for 24 hours at $50^{\circ} \mathrm{C}$ for drying. The dried samples were used for proximate analysis and mineral contents. The weight of dried fish was measured and homogenization was carried out by the use of homogenizer and a grinder mixture. The weight of homogenized samples of fish were recorded and placed in zipper bags, sealed and refrigerated until analysis Figures 3A-3F. The oven dried and minced samples were sent to National Food Research Center, Khumaltar for proximate and mineral analysis.

The proximate composition of the samples was determined following standard Association of Official Analytical Chemists (AOAC) procedures (2005) [28]. Moisture was determined by drying at $105^{\circ} \mathrm{C}$ to a constant weight. Nitrogen was estimated by the Kjeldahl method (2200 Kjeltec, Foss Tecator, Sweden) and crude protein was estimated by multiplying the per cent nitrogen by 6.25. The ether extract was measured by the solvent extraction method (1045 Soxtec, Tecator, Sweden) using diethyl ether as a solvent. Total ash was determined by using muffle furnace following standard AOAC methods [28]. In minerals iron, phosphorous, and calcium were analyzed by following [29] standard methods.

Total carbohydrate and energy were calculated by following equation.

Total Carbohydrate: 100 - (Moisture + Protein + Fat + Ash)

Energy: (4 X Total Carbohydrate) + (4 X Protein) + (Fat X 9)

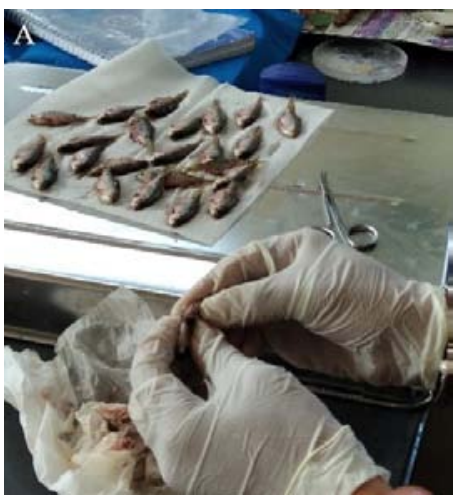

(A) Gutting of fish

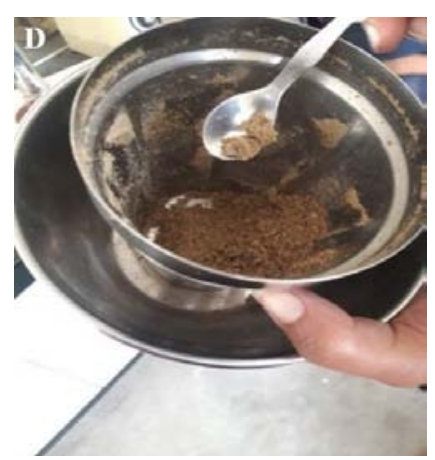

(E) Seiving of the dried samples

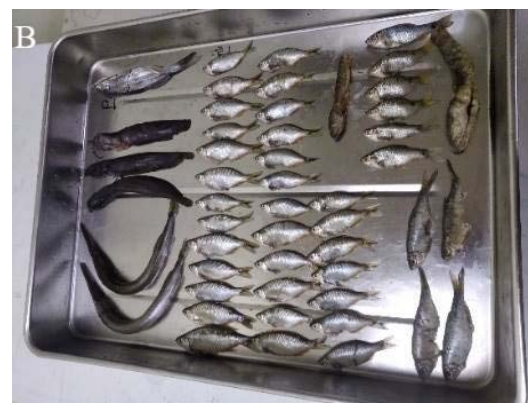

(B) Gutted fish samples

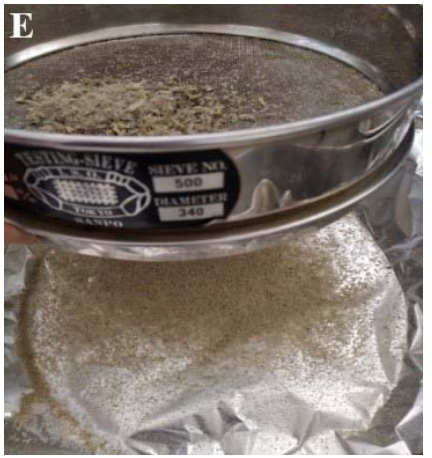

(D) Homogenized dried fish

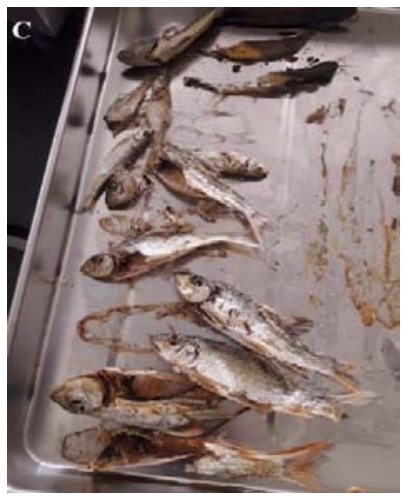

(C) Oven dried fish

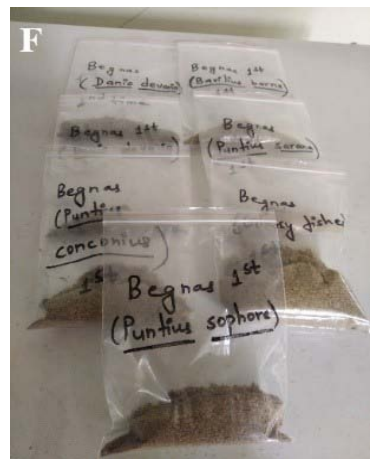

(F) Packing of final sample

Figure 3. Process of sample preperation of native fish species for nutrients analysis (A-F). 


\section{Results}

\subsection{Nutrients Level in fish species}

The present findings of nutrients contents (Mean \pm SD) of oven dry of fresh collected native fishes of Begnas Lake are presented in Table 2. The results showed that nutrients contents were varied in the studied native fish species of Begnas Lake. Among the eleven native fish species, the lowest crude protein was found in Puntius sophore (43.46 \pm $1.2 \%)$ and highest in the Labeo rohita (66.10 $\pm 0.71 \%)$. The moisture (\%) were varied from 4.71 to 8.39 with lowest in the Mastacembelus armatus $(4.7 \pm 0.21)$ and highest in the Puntius sophore $(8.39 \pm 2.11)$. The results showed that crude fat (\%) was found lowest in the Xenentodon cancila (6.24 \pm 0.21$)$ and highest in the Cirrhinus reba (17.28 \pm 0.04). The results showed that ash (\%) were varied from 12.64 to 19.65 with lowest in the Barilius barna (12.64 \pm 0.31$)$ and highest in the Puntius conchonius (19.65 \pm 1.54). Carbohydrate was found highest in the Puntius sophore (17.91) and lowest in the Channa punctatus (0.96). Energy (Kcal/g) was highest in the Cirrhinus reba (402.80) and lowest in the Xenentodon cancila (322.36).

Table 2. Nutrients level (oven dry basis, Mean \pm SD) of fresh collected native fishes of Begnas Lake

\begin{tabular}{cccccccc}
\hline S.N. & Fish species & $\begin{array}{c}\text { Crude Protein } \\
(\mathbf{\%})\end{array}$ & $\begin{array}{c}\text { Moisture } \\
\mathbf{( \% )}\end{array}$ & $\begin{array}{c}\text { Ash } \\
\mathbf{( \% )}\end{array}$ & $\begin{array}{c}\text { Crude fat } \\
\mathbf{( \% )}\end{array}$ & $\begin{array}{c}\text { Carbohydrate } \\
\mathbf{\%}\end{array}$ & $\begin{array}{c}\text { Energy } \\
(\mathbf{K c a l} / \mathbf{g})\end{array}$ \\
\hline 1 & Tor putitora & $57.23 \pm 5.5$ & $5.92 \pm 2.2$ & $14.16 \pm 0.59$ & $14.23 \pm 0.21$ & 8.46 & 390.83 \\
\hline 2 & Labeo rohita & $66.10 \pm 0.71$ & $5.91 \pm 0.07$ & $13.48 \pm 0.14$ & $11.43 \pm 0.14$ & 3.08 & 379.59 \\
\hline 3 & Cirrhinus reba & $46.10 \pm 2.5$ & $5.86 \pm 2.38$ & $15.04 \pm 1.12$ & $17.28 \pm 0.04$ & 15.72 & 402.80 \\
\hline 4 & Mastacembelus armatus & $56.74 \pm 0.70$ & $4.71 \pm 0.21$ & $16.23 \pm 0.31$ & $6.39 \pm 0.42$ & 15.94 & 348.23 \\
\hline 5 & Xenentodon cancila & $55.05 \pm 0.71$ & $8.33 \pm 0.35$ & $18.88 \pm 0.14$ & $6.24 \pm 0.21$ & 10.84 & 322.36 \\
\hline 6 & Puntius sophore & $43.46 \pm 1.2$ & $8.39 \pm 2.11$ & $17.39 \pm 1.65$ & $12.85 \pm 0.12$ & 17.91 & 361.13 \\
\hline 7 & Puntius conchonius & $60.44 \pm 1.2$ & $6.88 \pm 2.14$ & $19.65 \pm 1.54$ & $12.45 \pm 0.11$ & 0.58 & 356.13 \\
\hline 8 & Danio devario & $63.28 \pm 1.3$ & $8.34 \pm 2.13$ & $13.66 \pm 1.63$ & $13.88 \pm 0.05$ & 0.84 & 381.40 \\
\hline 9 & Mystus bleekeri & $65.14 \pm 0.8$ & $7.61 \pm 0.38$ & $15.53 \pm 0.34$ & $11.61 \pm 0.16$ & 0.12 & 365.53 \\
\hline 10 & Channa punctatus & $64.68 \pm 0.9$ & $7.45 \pm 0.45$ & $16.40 \pm 0.21$ & $10.51 \pm 0.17$ & 0.96 & 357.15 \\
\hline 11 & Barilius barna & $61.87 \pm 0.5$ & $8.35 \pm 0.64$ & $12.64 \pm 0.31$ & $12.66 \pm 0.12$ & 4.48 & 379.34 \\
\hline
\end{tabular}

\subsection{Minerals level in fish species}

The present findings of minerals contents (Mean \pm SD) oven dry of fresh collected native fishes of Begnas Lake are presented in Table 3. The results showed that minerals contents were varied in the studied native fish species of Begnas Lake. The results showed that phosphorus contents (mg/100g) was lowest in Puntius sophore (917.02 \pm 33.05$)$ and highest in Channa punctatus (4510.80 \pm 43.01$)$. Iron content $(\mathrm{mg} / 100 \mathrm{~g})$ was lowest in Danio devario $(1.65 \pm 0.07)$ and highest in Cirrhinus reba (12.36 \pm 0.18$)$. Calcium content $(\mathrm{mg} / 100 \mathrm{~g})$ was found lowest in Xenentodon cancila $(3,442.51 \pm 140.71)$ and highest in Puntius conchonius $(6,282.45 \pm 137.83)$.

Table 3. Minerals level (oven dry basis, Mean \pm SD) of 11 native fish species of Begnas Lake

\begin{tabular}{ccccc}
\hline S.N. & Fish species & Phosphorous $\mathbf{( m g / 1 0 0 g )}$ & Iron (mg/100g) & Calcium (mg/100g) \\
\hline 1 & Tor putitora & $1,727.79 \pm 71.41$ & $9.71 \pm 0.04$ & $5,223.75 \pm 138.59$ \\
2 & Labeo rohita & $2,167.77 \pm 31.11$ & $6.61 \pm 0.14$ & $4,355.14 \pm 211.42$ \\
3 & Cirrhinus reba & $1,887.82 \pm 69.29$ & $12.36 \pm 0.18$ & $5,476.94 \pm 142.12$ \\
4 & Mastacembelus armatus & $2,158.65 \pm 54.44$ & $10.48 \pm 0.07$ & $3,443.01 \pm 140.71$ \\
5 & Xenentodon cancila & $2,176.65 \pm 28.99$ & $10.43 \pm 0.14$ & $3,442.51 \pm 140.71$ \\
6 & Puntius sophore & $917.02 \pm 33.05$ & $6.94 \pm 0.07$ & $4,950.86 \pm 137.81$ \\
7 & Puntius conchonius & $924.37 \pm 43.02$ & $3.10 \pm 0.07$ & $6,282.45 \pm 137.83$ \\
8 & Danio devario & $967.59 \pm 22.03$ & $1.65 \pm 0.07$ & $4,596.80 \pm 136.82$ \\
9 & Mystus bleekeri & $4,312.50 \pm 23.03$ & $4.88 \pm 0.07$ & $4,797.77 \pm 134.81$ \\
10 & Channa punctatus & $4,510.80 \pm 43.01$ & $7.82 \pm 0.07$ & $5,233.06 \pm 132.83$ \\
11 & Barilius barna & $2,552.49 \pm 53.03$ & $4.04 \pm 0.07$ & $5,827.32 \pm 135.81$ \\
\hline
\end{tabular}




\section{Discussions}

Awareness about the importance of diet in human health is increasing day by day. A portion of $150 \mathrm{~g}$ of fish can provide about 50-60 percent of an adult's daily protein requirement [30]. Fishes are of high nutritional value and a good source of protein, minerals, low saturated fat and sufficient omega fatty acid, which requires for good health [31, 32]. Fish protein is a good source of essential amino acid. In addition to that, eicosapentaenoic acid (EPA) and docosahexaenoic acid (DHA) are also found in fish tissues, which play an important role in prevention of cardiovascular diseases, cancers, rheumatoid arthritis, and inflammation [33, 34 ].

\subsection{Nutrients Level in fish species}

In the present findings, highest level of $66.10 \pm 0.71 \%$ crude protein was found in the Labeo rohita (Table 2). Crude protein contents in the sun dried rohu (Labeo rohita) was reported 59.2\% [35], while [36] was reported $72.63 \pm 0.1 \%$ in the powder of sun and mechanical dried rohu (Labeo rohita). In the present study, the crude protein contentin Puntius sophore was $43.46 \%$ is close to protein content (42.4\%) reported by [37]. However, [38] was found higher protein contents (55.5\%) in the Puntius sophore. Crude protein (\%) was found $64.68 \pm 0.9$ in the snake head (Channa punctatus) in the present findings. It is higher to [35] findings of $62.85 \%$ protein contents in the sun dried snake head (Channa punctatus). The crude protein contents was found $57.23 \pm 5.5 \%$ in the oven dried Sahar (T. putitora) in the present findings, which is slightly higher than the crude protein contents reported by [22] which was $53.9 \pm 5 \%$ in the smoked $T$. putitora. The crude protein contents in Mystus bleekeri was $65.14 \pm 0.8 \%$ in the present study, which is higher than the report of [39] where the protein was $53.45 \%$ in Mystus vittatus.

In the present study, the moisture were varied from $4.7 \%$ to $8.39 \%$ in native fish species of Begnas Lake with lowest in the Mastacembelus armatus ( $4.7 \pm 0.21 \%)$ and highest in the Puntius sophore (8.39 \pm 2.11$)$ (Table 2). The previous findings had documented wide variations of moisture contents in the fish species. For example, lowest moisture content was found in oven dried Mystus cavasius (6.25 $\pm 0.24 \%)$ and highest in the C. punctatus (11.45 $\pm 0.72 \%)$ [40]. Similarly, the moisture content was found $7.81 \%$ in Phabaonga (Puntius shalynius) in traditional dried method [41] and it varied from $11.17 \%$ (L. bata and C. catla) to $14.17 \%$ (C. fasciata) local fish species [42]. Likewise, [43] was reported moisture were ranged from $3.82 \%$ in O. niloticusto $10.26 \%$ in C. gariepinus.

The results showed that crude fat was lowest in the Xenentodon cancila $(6.24 \pm 0.21 \%)$ and highest in the Cirrhinus reba (17.28 $\pm 0.04 \%)$ (Table 2). The present findings showed that crude fat of oven dried Puntius sophore and Tor putitora were $12.85 \pm 0.12 \%$ and $14.23 \pm 0.21 \%$ respectively. Fat content was found $7.7 \pm 1.2 \%$ in sun-dried Sidra ( $P$. sophore) and13.3 $\pm 2.1 \%$ in smoked Sahar (T. putitora) [22]. Another study had reported that fat contents were varied from $7.01 \%$ in O. niloticus to $8.10 \%$ in C. gariepinus [43].

The results showed that ash contents were varied from $12.64 \%$ to $19.65 \%$ with lowest in the Barilius barna (12.64 \pm 0.31 ) and highest in the Puntius conchonius (19.65 \pm 1.54 ) in the studied native fish species of Begnas Lake (Table 2). The previous findings had documented wide variations of ash contents in the fish species. The ash content of dried fish ranged from $11.17 \%$ (Tor tor) to $29.197 \%$ in P. shalynius [41], $21 \pm 0.4 \%$ in oven dried powder of Labeo rohita [36], $4.34 \pm 0.23 \%$ in $M$. pancalus to $18.43 \pm 0.77 \%$ in M. cavasius oven dried fish species [40] and $8.96 \%$ in C. gariepinus to $13.42 \%$ in O. niloticus [43].

Carbohydrate was found highest in the Puntius sophore (17.91\%) and lowest in the Channa punctatus (0.96\%) in the present study (Table 2). The previous findings had documented wide variations of carbohydrate contents in the fish species. The carbohydrate was reported $3.7 \%$ in the $L$. rohita by [44] which is higher than present study (3.07\%). Some authors had reported that carbohydrate was found highest (6.01\%) in H. molitrix and lowest (3.40\%) in A. grammepomus [36], and it varied from $7.25 \%$ in C. gariepinus to $14.60 \%$ in O. niloticus [43].

Energy (Kcal/100g) contents was found lowest in the Xenentodon cancila (322.36) and highest in the Cirrhinus reba (402.8) in the presents study (Table 2). The findings of present study of energy contents in Labeo rohita (379.59 $\mathrm{Kcal} / 100 \mathrm{~g}$ ) is higher than reported energy contents of $L$. rohita $(367.50 \mathrm{Kcal} / 100 \mathrm{~g}$ ) by [36] and lower than [44] findings of energy contents (466 Kcal/100g) in L. rohita. Likewise, the energy contents reported in Puntius puntio was $361.13 \mathrm{Kcal} / 100 \mathrm{~g}$ and in C. punctata was $371.95 \mathrm{Kcal} / 100 \mathrm{~g}$ [36], in C. striatus was $504 \mathrm{Kcal} / 100 \mathrm{~g}$ [45].

\subsection{Minerals levels in the fish species}

The results showed that phosphorus contents was lowest in Puntius sophore (917.02 mg/100g) and highest in Channa punctatus $(4,510.8 \mathrm{mg} / 100 \mathrm{~g}$ ) (Table 3). Phosphorus content in Labeo rohita was reported 1,493.7mg/100g by [46] is lower than our results of phosphorus content in Labeo rohita 2,177.77mg/100g. The previous findings had documented wide variations of phosphorus contents in the fish species. Phosphorus content varied from $727 \mathrm{mg} / 100 \mathrm{~g}$ in Lates niloticus to $935 \mathrm{mg} / 100 \mathrm{~g}$ in Oreochromis niloticus commercial Nile fishes [47], $510 \pm 59 \mathrm{mg} / 100 \mathrm{~g}$ in Encrasicholina devisi to $1,200 \pm 290 \mathrm{mg} / 100 \mathrm{~g}$ in Leiognathus dussumieri of small size marine fish species [48], and it varied from 1,073.8 \pm 9 
$\mathrm{mg} / 100 \mathrm{~g}$ in Pike (Esox lucius) to 1,165.4 $\pm 87 \mathrm{mg} / 100 \mathrm{~g}$ in pearch (Perca fluviatilis) fresh water fish species of Mazuarian great lakes [49].

In the present findings, the iron content (mg/110g) was lowest in Danio devario (1.65 \pm 0.07$)$ and highest in Cirrhinus reba (12.36 \pm 0.18 ) (Table 3$)$. The previous findings had documented wide variations of iron contents in the fish species. Iron contents varied from $0.04 \mathrm{mg} / 100 \mathrm{~g}$ in Puntius conchonius to $22.7 \mathrm{mg} / 100 \mathrm{~g}$ in Amblypharyngodon mola fish species found in the Brahmaputra River [50], $7.91 \pm 0.01 \mathrm{mg} / 100 \mathrm{~g}$ in Schistura khugae to $24.69 \pm 0.07 \mathrm{mg} / 100 \mathrm{~g}$ in Raiamas guttatus cyprinid fish species from different hill districts of Manipur, India [51], and rich in SIS Puntius sophore $(10.31 \pm 0.2) \mathrm{mg} / 100 \mathrm{~g}[2]$.

The calcium content was found lowest in Xenentodon cancila $(3,442.51 \pm 140.71 \mathrm{mg} / 100 \mathrm{~g})$ and highest in Puntius conchonius $(6,282.45 \pm 137.8 \mathrm{mg} / 100 \mathrm{~g}$ ) in present study (Table 3). The previous findings had documented wide variations of calcium contents in the fish species. Calcium contents were found: 1,984.32 \pm 1.1 (mg/100g) in the Puntius sophore, 1,267 $\pm 2.2(\mathrm{mg} / 100 \mathrm{~g})$ in the Amblypharyngodon mola, and 1,100.6 $\pm 1.21(\mathrm{mg} / 100 \mathrm{~g})$ in Gudusia chapra [2], $160 \mathrm{mg} / 100 \mathrm{~g}$ in Heteropneustes fossilis and 2,000 mg/100g in Salmophasia bacaila [50].

In the present study, the nutrients contents were varied in the fish species of Begnas Lake. When comparing to other previous studies, same species nutrients contents were found to differ from the present study. It may be due to difference of size, climatic condition and season as well as sample preparation methods. Many authors had suggested the variations of nutrients in the same fish species and as well as other species. The authors had reported that nutrients values were vary substantially within and between species, size, sexual condition, feeding season, habitat, feeding behavior, and physical activity [12, 13, 14, 52, 53]. Moreover, the proximate composition of fish species were found to greatly varies during the catching season due to physiological reasons and changes in environmental conditions [54]. Additionally, fatty acid contents, were found to vary from species to species and, also differ within the species under the influence of geographical location, food availability, environment, season, size, age, and maturation status of fish [55, 56]. In addition, the different processing methods (such as drying, smoking, freezing, cooking and canning of fish) were found to effect on the chemical, physical and nutritional compositions of fish [34].

The recommended dietary allowance (RDA) value for children, women and man in Nepal are: Protein 16.7 to 60 gm/day, net energy (kcal/day) 1,060-3,490, calcium 500-1,200 mg/day, and iron 09-35 mg/day [57]. The present findings showed that the eleven native fish species of Begnas Lake is nutrient-dense. The crude protein varies $43.46 \%$ to $66.10 \%$, energy $322.36 \mathrm{kcal} / \mathrm{g}-402.80 \mathrm{kcal} / \mathrm{g}$, calcium content 3,442.51 mg/100g to 6,282.45 mg/100g, and iron content $1.65 \mathrm{mg} / 100 \mathrm{~g}-12.36 \mathrm{mg} / 100 \mathrm{~g}$. The consumption of 100-200 gm dried or equivalent weight of fresh fish of these fish species will alone provide the recommended dietary allowance (RDA) value of protein, iron, calcium and energy, particularly for children, women, and general peoples of Nepal to combat the nutritional deficiencies.

\section{Conclusion}

The present study has documented the nutrients profile of eleven oven dried native fish species of Begnas Lake. The results showed that the native fishes of Begnas Lake were nutrient-dense and can ensure nutritional security. These indigenous fishes can improve the nutritional security of women and child of this area, and consumption of these fish species might reduce the extent of malnutrition. This is preliminary study of limited fish species. However, it will be useful to make the recommendations of dietary plan for the people of this region as well as Nepal. Further study should be continued on more fish species with additional nutritional aspects.

\section{Acknowledgements}

The authors gratefully acknowledge the contribution of staffs of National Food Research Center, Khumaltar for the analysis of fish samples and staffs of Fishery Research Station, Begnas for collections and preparations of fish samples. This study fund was granted from Nepal Agricultural Research Council (NARC) project No. 134.

\section{References}

[1] Larsen, R., Eilertsen, K. E., Elvevoll, E. O. (2011). Health benefits of marine foods and ingredients. Biotechnology Advances, 29(5): 508-518.

[2] Zaman, M., Naser M. N., Abdullah A. T. M., and Khan N. (2014). Nutrient contents of some popular freshwater and marine fish species of Bangladesh. Bangladesh Journal of Zoology, 42(2): 251-259.

[3] Jena, D., Jena A. K., Panda A., Parhi J., Biswas P., and Pattanaik S. S. (2018). Proximate analysis of some small indigenous fish species (SIS) of Tripura, India. Journal of Entomology and Zoology Studies, 6(4): 470-474.

[4] Bene, C., Arthur, R., Norbury, H., Allison, E. H., Beveridge, M., Bush, S., et al. (2016). Contribution of fisheries and aquaculture to food security and poverty reduction: assessing the current evidence. World Development, 79: 177-196. FAO, 2018. The State of World Fisheries and Aquaculture. Retrieved from http://www.fao.org/documents/card/en/c/I9540EN/. 
[5] Hicks, C. C., Cohen, P. J., Graham, N. A. J., Nash, K. L., Allison, E. H., D’Lima, C., et al. (2019). Harnessing global fisheries to tackle micronutrient deficiencies. Nature. https://doi. org/10.1038/s41586-019-1592-6.

[6] Thilsted, S. H., Wahab, M. A. (2014). Nourishing Bangladesh with Micronutrient-Rich Small Fish. Policy Brief: AAS-2014-08. Available from: http://www.worldfishcenter. org/resource_centre/AAS-2014-08.pdf (retrieved 01.05.14), WorldFish, CGIAR Research Program on Aquatic Agricultural Systems, Penang, Malaysia.

[7] Huynh, M. D., Kitts, D. D. (2009). Evaluating nutritional quality of pacific fish species from fatty acid signatures. Food Chemistry, 114: 912-918.

[8] Zhao, F., Zhuang, P., Song, C., Shi, Z., Zhang, L. (2010). Amino acid and fatty acid compositions and nutritional quality of muscle in the pomfret, Pampus punctatissimus. Food Chemistry, 118: 224-227.

[9] Ahmed, S., Rahman, A. F. M. Arifur, Mustafa, M. G., Hossain, M. B., and Nahar, N. (2012). Nutrient composition of indigenous and exotic fishes of rainfed waterlogged paddy fields in Lakshmipur, Bangladesh. World Journal of Zoology, 7(2): 135-140.

[10] Dhaneesh, K. V., Noushad, K. M., Ajith, K. T. T. (2012). Nutritional Evaluation of Commercially Important Fish Species of Lakshadweep Archipelago, India. PLoS ONE, 7(9): e45439. doi:10.1371/journal.pone.0045439.

[11] Bogard, J. R., Thilsted, S. H., Marks G. C., Wahab M. A., Hossain M. A. R., Akobsen J. J., Stangoulis J. (2015). Nutrient composition of important fish species in Bangladesh and potential contribution to recommended nutrient intakes. Journal of Food Composition and Analysis, 42: 120-133.

[12] Mohanty, B. P., Sankar, T. V., Ganguly, S., Mahanty, A., Anandan, R., Chakrabarty, K., et al. (2016). Micronutrient composition of 35 food fishes from India and their significance in human nutrition. Biological Trace Element Research, 174: 448-458.

[13] Sikandar, M. A., Hassan, Z., Basit, A., Khan, R., Ozdemir, F. A. (2020). Virtual analysis on proximate body composition of Labeo rohita and Cirrhinus mrigala. Turkish Journal of Agriculture-Food Science and Technology, 8(1): 105-109.

[14] Islam, R., Hossain M. B., Islam M. N., Islam M. M., Islam M. T. (2020). Nutrient composition of small indigenous fish species (SIS) from homestead ponds of Noakhali Coast, Bangladesh. Egyptian Journal of Aquatic Biology \& Fisheries, 24(7): 943-954.

[15] Rajbanshi, K. G. (2012). Biodiversity and distribution of fresh water fishes of Central-Nepal Himalayan region. Nepal Fisheries Society. Kathmandu. P. 65.

[16] Husen, M. A., Gurung, T. B., Nepal, A. P. (2019). Drivers of fisheries and its management in the lakes of Pokhara Valley, Nepal. Journal of Fisheries, 7(2): 706-713.

[17] MOH (Ministry of Health), New ERA, and ICF. (2017). Nepal Demographic and Health Survey 2016. Kathmandu, Nepal: Ministry of Health, Nepal.

[18] Gurung, T. B. (2016). Role of inland fishery and aquaculture for food and nutrition security in Nepal. Agriculture\& Food Security, 5: 18. https://doi.org/10.1186/s40066-016-0063-7.

[19] Rai, S., Thilsted, S. H., Shrestha, M. K., Wahab, A. M.D., Gharti, K. (2012). Improvement of women's livelihoods, income and nutrition through carp sis- prawn polyculture in terai, Nepal. Asian Fisheries Science, special issue 25S: 217-225.

[20] Pradhan, N., Roy, N. K., Wagle, S. K., and Shrestha, M. B. (2012). Proximate and microbial analysis of fresh, dried and fried naini fish (Cirrhinus mrigala). In: Pradhan, S. M., Upreti, C. R., Paudel, S. K., Wagle, S. K., Shreshtha, B. S., and Sanjal, S. (eds.), Proceedings of the $6^{\text {th }}$ NASA Convection 2011" commercialization of livestock production for food security and prosperity 25-26 September 2011. Nepal Animal Science Association NASC, Jawalakhel Lalitpur. Pp. 267-271.

[21] Pradhan, N., Shrestha M. K., Rai, S., Jha D. K., and Sah, S. K. (2016 \& 2017). Biochemical assessment of dried fish products of Nepal. Nepalese Journal of Aquaculture and Fisheries, (3 \& 4): 47-58.

[22] Pradhan, N., Shrestha, M. K., Rai, S., Jha, D. K., and Sah, S. K. (2018). Quality assessment of dried mrigal (Cirrhunus mrigala) chhari fish from different market outlets of Nepal. International Journal of Fisheries and Aquatic Studies, 6(2): 463-471.

[23] Pradhan, N., Shrestha, M. K., Rai, S., Jha, D. K., Sah, S. (2020). Evaluation of Different Drying Methods on Shelf-life Quality of Mrigal Cirrhinus mrigala (Hamilton, 1822). Asian Fisheries Science, 33: 31-41.

[24] Husen, M. A., Bista, J. D., Dhakal, R. P., Prasad, S., and Nepal, A. (2012). Trophic status of Phewa, Begnas and Rupa lakes of Pokhara valley, Nepal. In: Pradhan, S. M., Upreti, C. R., Paudel, S. K. Wagle, S. K., Shreshtha, B. S., and Sanjal,S.(eds), Proceedings of the $6^{\text {th }}$ NASA Convection 2011" commercialization of livestock production for food security and prosperity 25-26 September 2011. Nepal Animal Science Association NASC, Jawalakhel Lalitpur. Pp. 261-266.

[25] Mo, F. E. (2018). Integrated Lake Basin Management Plan of Lake Cluster of Pokhara Valley, Nepal (2018-2023). Ministry of Forests and Environment, Kathmandu, Nepal, p. 185.

[26] Shrestha, T. K. (2008). Ichthyology of Nepal. Himalayan Ecosphere. Kathmandu, Nepal. P. 389.

[27] AOAC. (2005). Official methods of analysis. 18th Edition. AOAC International, USA. P. 105.

[28] AOAC. (2000). Official methods of analysis. Association of Official Analytical Chemists, Inc., Washington, DC, USA.

[29] FAO (Food and Agriculture Organization). (2015). Statistical pocketbook: World food and agriculture. Rome: FAO. Accessed 08 May 2021. http://www.fao.org/3/a-i4691e.pdf. 
[30] Palani, K. M., Ruba, A. A., Jeya, S. R., and Shanmugam, S. A. (2014). Proximate and major mineral composition of 23 medium sized marine fin fishes landed in the Thoothukudi Coast of India. Journal of Nutrition \& Food Sciences, 4: 1.

[31] Ahmed, E. O., Ahmed, A. M., Ebrahim, S. J., and Adm, H. H. (2017). Proximate and mineral composition of some commercially important fishes in Jebl Awlia reservoir, Sudan. International Journal of Fisheries and Aquaculture Research, 3: 51-57.

[32] Rahman, R., Chowdhury, M. M., Sultana, N., and Saha, B. (2018). Proximate and Major Mineral Composition of Commercially Important Marine Fishes of Bangladesh. Journal of Agriculture and Veterinary Science, 11(1): 18-25.

[33] Abraha, B., Admassu, H., Mahmud, Tsighe, N., Shui, X. W., and Fang, Y. (2018). Effect of processing methods on nutritional and physico-chemical composition of fish: a review. MOJ Food Process Technology, 6(4): 376-382.

[34] Mansur, M. A., Rahman, S., Khan, M. N. A., Reza, M. S., and Uga, S. (2013). Study on the quality and safety aspect of three sun-dried fish. African Journal of Agricultural Research, 8: 5149-515.

[35] Mahmud, N., Al-Fuad, S., Satya, S. I., Mamun, A. A., Ahmed, S., Karim, A., Islam, M., Ferdaus, J., Islam, S., Sakib, N., and Yeasmin, J. (2019). Development and biochemical composition assessment of fish powders from Bangladeshi indigenous fish species and shelf-life characteristics evaluation during 90 days of room temperature $\left(27^{\circ} \mathrm{C}-30^{\circ} \mathrm{C}\right)$ storage. Food and Nutrition Sciences, 10: 963-984.

[36] Majumdar, B. C. (2017). Comparison of the changes in nutritional quality of three important small indigenous fish species in Bangladesh at room temperature $\left(27^{\circ} \mathrm{C}-31^{\circ} \mathrm{C}\right)$ : A review. Journal of Animal Research and Nutrition, 2(2): 15.

[37] Hossain, M. A., Afsana, K., and Shah, A. K. M. A. (1999). Nutritional value of some small indigenous fish species (SIS) of Bangladesh. Bangladesh J. Fish. Res., 3(1): 77-85.

[38] Flowra, A. F., Nahar, D. G., Tumpa, S. A., and Islam, M. T. (2012). Analysis of five dried fish species of Bangladesh. University Journal of Zoology, Rajshahi University, 21: 9-11.

[39] Jahan, S. N., Chhabi, I. J., Samad, M. A., and Hossain, M. I. (2018). Comparative study on nutritional quality of sun dried fish and oven dried fish. Proceedings of ISER 158th International Conference, Rome, Italy, 25th-26th September 2018. Pages 7-10. (Retrieved on 5/20/2021.https://www.worldresearchlibrary.org/up_proc/pdf/1944-154098742607-10.pdf).

[40] Ullah, N., Hazarika, P., and Handique, P. J. (2016). Biochemical quality assessment of ten selected dried fish species of north east India. International Advanced Research Journal in Science, Engineering and Technology, 3(1): 30-33.

[41] Debnath, C., Sahoo L., Singha, A., Yadav, G. S., Datta, M., and Ngachan, S. V. (2014). Protein and mineral compositions of some local fishes of Tripura, India. Indian Journal of Hill Farming, 27(1): 120-123.

[42] Mustapha, M. K., Ajibola, T. B., Ademola, S. K., and Salako, A. F. (2014). Proximate analysis of fish dried with solar driers. Italian Journal of Food Science, 26: 221-226.

[43] Jabeen, F. and Chaudhry, A. S. (2016). Nutritional composition of seven commercially important freshwater fish species and the use of cluster analysis as a tool for their classification. The Journal of Animal \& Plant Sciences, 26(1): 282-290.

[44] Paul, B. N., Chanda, S., Sridhar, N., Saha, G. S., and Giri, S. S. (2016). Proximate, mineral and vitamin contents of Indian major carp. Indian Journal of Animal Nutrition, 33(1): 102-107.

[45] Jabeen, F., Noureen, A., Hussain, S. M., Chaudhry, A. S., Irfan, M., Shakeel, M., Shabbir, S., Yaqub, S., Ahmad, S., and Shaheen, T. (2015). Chemical and mineral composition of Cyprinus carpio, Labeo rohita and Wallago attu inhabiting river indus in Mianwali district. International Journal of Bioscience, 6(5): 333-342.

[46] Elagba, H. A. M., Al-Maqbaly, R., and Mansour, H. M. (2010). Proximate composition, amino acid and mineral contents of five commercial Nile fishes in Sudan. African Journal of Food Science, 4(10): 650-654.

[47] Reksten, A. M., Somasundaram, Kjellevold, T. M., Nordhagena, A., Bokevoll, A., Pincus, L. M., Rizwan, A. A. M., Mamun, A., Thilsted, S. H., Htutf, T., and Aakre, I. (2020). Nutrient composition of 19 fish species from Sri Lanka and potential contribution to food and nutrition security. Journal of Food Composition and Analysis, 91: 1-13.

[48] Luczynska, J., Tonska, E., and Luczynski, J. (2009). Essential mineral components in muscles of six freshwater fish from the Mazurian Great Lakes (northeastern Poland). Arch Pol Fish., 17: 171-178.

[49] Eti, M. S. A., Zakir, H. M., Quadir, Q. F., and Rahman, M. S. (2019). Protein and Mineral Contents in Some Fish Species Available in the Brahmaputra River of Bangladesh. European Journal of Nutrition \& Food Safety, 11(1): 14-27.

[50] Romharsha, H. and Sarojnalini, C. (2018). Proximate composition, total amino acids and essential mineral elements of some cyprinid fishes of Manipur, India. Current Research in Nutrition and Food Science, (06) (1): 157-164.

[51] Effiong, B. N. and Mohammed, I. (2008). Effect of seasonal variation on the nutrient composition in selected fish species in Lake Kainji Nigeria. Nature \& Science, 6(2): 1-5.

[52] Akinneye, J. O., Amoo, I. A., and Bakare, O. O. (2010). Effect of drying methods on the chemical composition of three species of fish (Bonga spp., Sardinella spp. and Heterotis niloticus). African Journal of Biotechnology, 9(28): 4369-4373.

[53] Boran, G. and Karaçam H. (2011). Seasonal Changes in Proximate Composition of Some Fish Species from the Black Sea. Turkish Journal of Fisheries and Aquatic Sciences, 11: 01-05.

[54] Grigorakis, K. (2007). Compositional and organoleptic quality of farmed and wild gilthead sea bream (Sparus aurata) and sea bass (Dicentrarchus labrax) and factors affecting it: a review. Aquaculture, 272: 55-75. 
[55] Anal, L. S. S., Iwamoto, A. A., Crepaldi, D. V., Boaventura, T. P., Teixeira, L. V., Teixeira, E. A., and Luz, R. K. (2019). Comparative study of the chemical composition, fatty acid profile, and nutritional quality of Lophiosilurus alexandri (Siluriformes: Pseudopimelodidae), a Brazilian carnivorous freshwater fish, grown in lotic, lentic, and aquaculture environment. Neotropical Ichthyology, 17(4): e190050.

[56] NFCT. (2017). Nepalese Food Composition Table 2017 (Third Ediion, 2017). GON, MOAD, Department of food technology and quality control, National Nutrition Program, Babarmahal, Kathmandu. P. 49. 